\title{
Haemorrhagic myelomalacia in a cat with extradural T-cell lymphoma
}

\section{Mielomalacia hemorrágica em um gato com linfoma de células $\mathrm{T}$ extradural}

\author{
Cláudio João Mourão Laisse ${ }^{1}$; Eduardo Conceição de Oliveira'; \\ Veronica Machado Rolim; Daiane de Oliveira Negreiros²; David Driemeier ${ }^{3}$; \\ Saulo Petinatti Pavarini ${ }^{*}$
}

\begin{abstract}
Myelomalacia is a term used to indicate the softening of the spinal cord, which results from ischaemic or haemorrhagic necrosis that can occur as a sequel to acute spinal cord injury. A 10-month-old, female, mixed breed domestic cat exhibiting neurological symptoms was referred for evaluation. Neurological examination revealed symptoms consistent with thoracolumbar syndrome. Initial radiographic examination detected no changes of the thoracolumbar spine. The cat received a palliative treatment with tramadol hydrochloride and prednisolone. The patient did not respond to the treatment and one month later presented with worsening of symptoms that progressed to non-ambulatory paraplegia. Radiographic examination was performed a second time and revealed a mass inside the spinal canal at the L1 and L3 vertebral levels. The animal died and was sent for post-mortem examination. The necropsy revealed a greyish-white epidural mass inside the spinal canal that was compressing the spinal cord at the L1 and L3 vertebral levels. The spinal cord between T2 and L3 was reddish and friable. The pancreaticoduodenal lymph node was enlarged. Histologically, the spinal cord mass and pancreaticoduodenal lymph node presented neoplastic lymphocyte proliferation, and haemorrhagic myelomalacia was observed in the spinal cord from T2 to L3. Immunohistochemistry revealed that the neoplastic lymphocytes were positive for CD3 antibody (T-cell lymphoma), and the lymphoid organs showed immunostaining for feline leukaemia virus (FeLV). Haemorrhagic myelomalacia due to extradural lymphoma should be considered as a differential diagnosis in cats with spinal neurological signs.
\end{abstract}

Key words: Cat. Spinal cord. T lymphocytes. FeLV. Immunohistochemistry.

\section{Resumo}

Mielomalácia é um termo utilizado para indicar amolecimento da medula espinhal, decorrente de necrose isquêmica ou hemorrágica que pode ocorrer como sequela de lesão medular aguda. Um felino doméstico, sem raça definida, fêmea, 10 meses de idade, com sintomas neurológicos foi avaliado. $\mathrm{O}$ exame neurológico constatou sinais clínicos compatíveis com síndrome toracolombar. Na primeira avaliação, no exame radiográfico não foram observadas alterações na coluna vertebral toracolombar. Foi realizado tratamento suporte a base de cloridrato de tramadol e prednisolona. $\mathrm{O}$ paciente não

${ }^{1}$ Discentes, Universidade Federal do Rio Grande do Sul, UFRGS, Porto Alegre, RS, Brasil. E-mail: claudiolaisse@yahoo.com.br; eduvetrs@yahoo.com.br; veronicarolim17@yahoo.com.br

${ }^{2}$ Médica Veterinária, Hospital de Clínicas Veterinárias, Faculdade de Veterinária, Universidade Federal do Rio Grande do Sul, HCV-FAVET-UFRGS, Porto Alegre, RS, Brasil. E-mail: daianegreiros@hotmail.com

${ }^{3}$ Prof., Universidade Federal do Rio Grande do Sul, UFRGS, Porto Alegre, RS, Brasil. E-mail: davetpat@ufrgs.br; sauloppvet@ yahoo.com.br

* Author for correspondence 
respondeu ao tratamento e um mês após a primeira avaliação clínica, apresentou piora do quadro clínico apresentando então paraplegia não ambulatória. No segundo exame radiográfico foi observada uma massa radiopaca no interior do canal vertebral, comprimindo a medula espinhal entre L1 e L3. O felino veio a óbito e encaminhado para exame post-mortem. Na necropsia, foi observada no canal medular a presença de uma massa branco-acinzentada, extradural, comprimindo à medula espinhal no segmento entre as vértebras lombares L1 e L3. A medula espinhal entre T2 até L3 estava hemorrágica e friável. O linfonodo pancreaticoduodenal estava aumentado. Na avaliação histológica, a massa observada no canal medular e linfonodo pancreaticoduodenal apresentaram proliferação de linfócitos neoplásicos e a medula espinhal entre T2 e L3 apresentou mielomalácia hemorrágica. No exame imuno-histoquímico, os linfócitos neoplásicos apresentaram marcação positiva para anticorpo CD3 (linfoma de células T) e os órgãos linfoides apresentaram imuno-marcação para o vírus da leucemia felina (FeLV). Mielomalácia hemorrágica causada por linfoma extradural deve ser considerada no diagnóstico diferencial em felinos FeLV positivos com sinais neurológicos medulares.

Palavras-chave: Gato. Medula espinhal. Linfócitos T. FeLV. Imuno-histoquímica.

\section{Introduction}

Myelomalacia is a pathological term referring to the softening of the spinal cord resulting from ischaemic or haemorrhagic necrosis that can occur as a sequel to acute spinal cord injury. The lesion may be focal or diffuse, involving the spinal cord. When the lesion is diffuse, it is called progressive haemorrhagic myelomalacia (TAYLOR, 2014). The main causes of myelomalacia are exogenous traumatic injuries of the spinal cord and intervertebral disc extrusion (LU et al., 2002; GIANOTTI et al., 2008; MACEDO et al., 2013; ZILIO; BAHR ARIAS, 2013; DE LA FUENTE et al., 2013).

Animals with myelomalacia present clinical signs that vary according to the location, extension and degree of the spinal cord injury. Affected animals frequently die because of breathing problems due to intercostal muscles and diaphragm paralysis (LU et al., 2002; ZILIO; BAHR ARIAS, 2013). A diagnosis of myelomalacia is based on the clinical history; presentation of progressive neurological spinal symptoms; findings from complementary exams, such as myelography, magnetic resonance imaging, and computer tomography; post-mortem findings; and the histopathological examination (LU et al., 2002; NEGRIN et al., 2009).

Myelomalacia is widely reported in dogs (LU et al., 2002; PLATT et al., 2006; GIANOTTI et al., 2008; MACEDO et al., 2013; ZILIO; BAHR
ARIAS, 2013) with few cases described in cats (NORTHINGTON; JULIANA, 1978; GÓMEZ et al., 2011; DE LA FUENTE et al., 2013). This paper reports the clinical, pathological and immunohistochemical findings in a case of haemorrhagic myelomalacia associated with extradural T-cell lymphoma in a domestic cat.

\section{Case Report}

A 10-month-old, mixed breed, female, domestic cat was referred with a five-day clinical history of walking difficulties, urination and reduced defecation frequency, with no history of trauma. Neurological examination of the cranial nerves and forelimb reflexes showed no abnormalities. In the hindlimbs, the patient presented non-ambulatory paraparesis, reduced conscious proprioception, slightly increased withdrawal reflex and a normal patellar reflex. The tail tone was decreased, and the perianal reflex was normal. Upon palpation, the cat had slightly increased sensitivity of the lower back. Radiographic examination revealed that the thoracolumbar spine was normal. An abdominal ultrasound showed that the bladder was full and difficult to empty upon compression. The blood haematological and biochemical test parameters were within normal limits. Urinalysis demonstrated clusters of bacteria and leukocytes. Escherichia coli was isolated from an aerobic culture of urine that 
was collected by natural urination. The SNAP ${ }^{\circledR}$ FIV/FeLV Combo Test (IDEXX Laboratories, Westbrook, ME, USA) was positive for feline leukaemia virus (FeLV) and negative for feline immunodeficiency virus (FIV).

Based on the clinical, laboratory and radiographic examinations, a presumptive diagnosis of feline leukaemia associated with thoracolumbar syndrome of an undetermined aetiology was established. The cat was subjected to a supportive therapy based on tramadol hydrochloride ( $2 \mathrm{mg}$ $\mathrm{kg}^{-1}$ s.i.d.) and prednisolone (1 $\mathrm{mg} \mathrm{kg}^{-1}$ s.i.d.). The cat did not respond to the therapy, and one month later showed worsening of neurological symptoms that progressed to non-ambulatory paraplegia. The animal also presented anorexia, weight loss and dyspnea. In the second clinical evaluation, x-ray of the spinal cord revealed a radiopaque mass inside the spinal canal compressing the spinal cord at the L1 and L3 vertebral levels, without causing bone lysis. A clinical diagnosis of spinal neoplasm was established. The cat died before being subjected to surgery to remove the mass in the spinal canal.

At necropsy, the cat was cachectic, and inside the spinal canal between the L1 and L3 vertebral levels, there was a $2.0 \times 1.0 \times 0.7 \mathrm{~cm}$, greyish-white extradural mass with an irregular surface that was compressing and causing reduction of the spinal cord diameter (Figure 1A). The spinal cord between the $\mathrm{T} 2$ and $\mathrm{L} 3$ vertebrae was bleeding and soft (Figures $1 \mathrm{~A}$ and $1 \mathrm{~B})$. One of the pancreaticoduodenal lymph nodes was enlarged $(2.5 \mathrm{~cm}$ in diameter) with soft and grey cut surfaces and without distinction of the cortical and medullar regions. The lungs were severely edematous, and other organs showed no macroscopic lesions.

Figure 1. Haemorrhagic myelomalacia associated with extradural T-cell lymphoma in a cat. A. Lymphoma compressing the spinal cord (thick arrow) at the L1 to L3 levels. The spinal cord from the T2 to the L3 level was bleeding and soft. The spinal cord cervical enlargement was not affected by myelomalacia (thin arrow). B. Cross-sections of the spinal cord fixed in $10 \%$ formalin showed marked reduction of the diameter between the L1 and L3 levels and myelomalacia in the L1 to L3 level and thoracic (T) segments. The cervical segment (C) was normal.

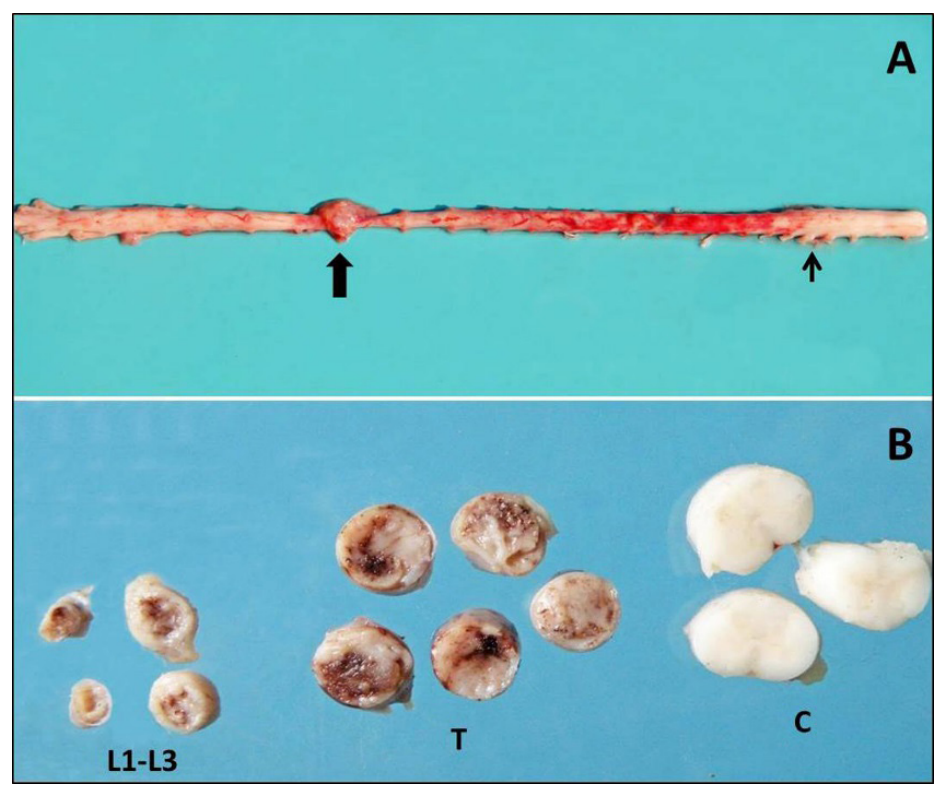

Fragments of different organs and tissues were collected and fixed in a $10 \%$ buffered formalin solution, processed for routine histopathologic examination and stained with haematoxylin 
and eosin (HE). Additionally, sections of the spinal canal mass, pancreaticoduodenal lymph node and other lymph nodes were subjected to immunohistochemistry (IHC) by applying the following primary antibodies: CD3 (Dako, 1:500), CD79a (Dako, 1:100), FeLV (Serotec, 1:500) and FIV (Serotec, 1:500). The alkaline phosphatase (Dako) detecting method was used for CD3, FeLV and FIV, and the Mack 4 method (Biocare Medical) was used for the CD79a antibody.

Immunostaining was enhanced with Permanent Red (Dako) for CD3, FeLV and FIV and 3'3-diaminobenzidine (DAB, Dako) for CD79a. The positive controls for IHQ consisted of cat normal lymph node and spleen for lymphocyte markers (CD3 and CD79a) and previously tested lymph nodes from cats infected with FeLV and FIV virus. Negative control sections were treated similarly with phosphate-buffered saline (PBS) instead of a primary antibody. Immunohistochemistry sections were counterstained with Harris haematoxylin.

Histologically, the mass of the spinal canal and the pancreaticoduodenal lymph node were composed of neoplastic lymphocytes that were densely arranged with little supporting connective stromal tissue (Figure 2A). The neoplastic cells had scant cytoplasm, spherical and often hyperchromatic nuclei, moderate anisocytosis and anisokaryosis, and an average of 4 mitotic figures per 10 high-power fields (400x). The spinal cord from the T2 to L3 level presented diffuse, marked malacia in the grey and white matter (Figure 2B) and had numerous gitter cells, microcavitations in the neuropil and large areas of haemorrhage and neovascularization (Figure 2C). Non-neoplastic cells infiltrating the spinal cord were observed. The remaining white matter showed marked Wallerian degeneration and moderate multifocal perivascular neutrophil infiltration. The lungs showed intense alveolar oedema, and other organs that were analysed showed no histological lesions. In IHC, neoplastic cells from the extradural mass and pancreaticoduodenal lymph node showed cytoplasmic immunostaining for CD3 (T-cell lymphoma) and were negative for CD79a. Lymphoid tissues showed immunostaining for FeLV (Figure 2D) and were negative for FIV.

Figure 2. Haemorrhagic myelomalacia associated with extradural T-cell lymphoma in a cat. A. Spinal canal neoplasm composed of aggregates of neoplastic lymphocytes that are densely arranged with little connective stromal tissue. (H.E., 10x objective). B. Myelomalacia in the spinal cord at the T2 to L3 level. (H.E., 10x objective). C. Myelomalacia in the thoracic spinal cord, with haemorragies, gitter cells and neuropil microcavitations. (H.E., 40x objective). D. Lymph node, cytoplasmic immunostaining in lymphocytes (IHC for FeLV, 40x objective).

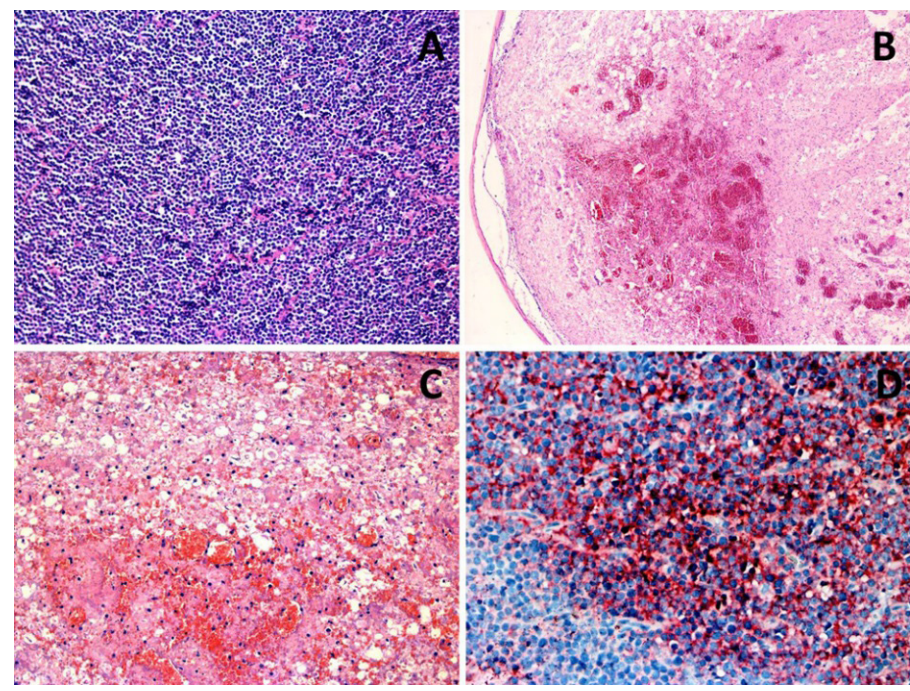




\section{Discussion}

We report a case of haemorrhagic myelomalacia associated with extradural T-cell lymphoma. The diagnosis was based on radiography, necropsy, histopathology and IHC examinations. In the literature, there are few cases that describe the occurrence of myelomalacia associated with extradural lymphoma in cats (NORTHINGTON; JULIANA, 1978). This report contributes one additional description, but it is distinct in that the lymphoma was phenotypically characterized using IHC and that the affected cat was demonstrated to be FeLV positive.

Other causes of myelomalacia in cats are spinal cord trauma (DE LA FUENTE et al., 2013), Gurltia paralysans infestation in the vessels of the spinal cord meninges (GÓMEZ et al., 2011) and fibrocartilaginous emboli (MARIONI-HENRY et al., 2004). Myelomalacia caused by extradural lymphoma has also been previously described in equine (ROUSSEAUX et al., 1989) and dog (ZILIO; BAHR ARIAS, 2013).

The neurological clinical signs presented in this case study are characteristic of an injury at the thoracolumbar spinal cord segment between the T3 and L3 levels (NORTHINGTON; JULIANA, 1978; MACEDO et al., 2013), which is characterized by paresis and ataxia related to upper motor neurons in the hindlimbs (NEGRIN et al., 2009; TAYLOR, 2014). In this study, myelomalacia occurred due to spinal cord compression that was caused by an extradural lymphoma.

Spinal cord compression results in haemodynamic changes, which consist of blood perfusion failure, vascular stasis, plasma protein extravasation, osmotic pressure increases in the spinal cord (VANDEVELDE et al., 2012), vasoconstrictor substance release, blood vessel thrombosis and catecholamines and amines release (HOERLEIN, 1978). The severity of spinal cord lesions due to compression varies with the extension and how fast the lesion occurred (VANDEVELDE et al., 2012).
In this case, the prognosis was unfavourable because myelomalacia affected an extensive segment of the spinal cord causing permanent neurological deficits (TAYLOR, 2014). In these unfavourable cases, euthanasia is recommended (ZILIO; BAHR ARIAS, 2013). The cat's anorexia and progressive weight loss worsened the clinical condition and may have been related to the immunodeficiency caused by the FeLV infection (MARIONI-HENRY et al., 2008). The dyspnea was due to the pulmonary edema observed during the post-mortem examination.

Differential diagnosis of spinal cord lymphoma in cats should consider other causes, such as skeletal malformations, vertebral fractures, intervertebral disc disease, hypervitaminosis A, cryptococcosis, toxoplasmosis, feline infectious peritonitis, bacterial myelitis and other neoplasms (osteosarcoma, meningioma and glioma) (NORTHINGTON; JULIANA, 1978; MARIONI-HENRY et al., 2004, 2008; NEGRIN et al., 2009; TAYLOR, 2014). In this case study, the first radiography did not detect the neoplasm in the spinal canal because it was small and did not affect the spine structure. For accurate differential diagnosis, other imaging diagnostic tests such as myelography, magnetic resonance and computed tomography should have been performed (NORTHINGTON; JULIANA, 1978, NEGRIN et al., 2009). These exams were not performed due to the patient's guardian's unfavourable financial situation and/or equipment unavailability.

Diagnostic imaging techniques are not always effective in detecting myelomalacia, thus, this condition is often diagnosed based on the postmortem and histopathological examinations (PLATT et al., 2006; GIANOTTI et al., 2008). The gross and histological characteristics of myelomalacia described in this case study are similar to those previously described in the literature (MACEDO et al., 2013; DE LA FUENTE et al., 2013).

Palliative treatment with a corticosteroid and an analgesic did not improve the patient's condition 
because the extradural lymphoma compressed the spinal cord causing diffuse and severe myelomalacia. Treatment of the extradural lymphoma before the spinal cord has irreversible lesions may result in a positive outcome. Curative treatment is performed with surgery, chemotherapy and radiotherapy. The surgical removal of spinal cord neoplasms can relieve pain and neurological signs caused by spinal cord compression (TAYLOR, 2014).

Lymphoma of the central nervous system in cats usually occurs concomitantly with lymphoma in the extraneural organs (MARIONI-HENRY et al., 2008; TAYLOR, 2014). Bone marrow, kidney, liver, skeletal muscle, spleen, lymph nodes, vertebrae and heart are the most affected organs and tissues (MARIONI-HENRY et al., 2008). In the case we describe here, the cat also presented with lymphoma in the pancreaticoduodenal lymph node. More than $80 \%$ of cats with spinal cord lymphoma are FeLV positive (WEISS et al., 2010; TAYLOR, 2014). The proportion of T-cell and B-cell lymphomas varies in different studies (GABOR et al., 1999; WEISS et al., 2010). In this case, the extradural lymphoma was derived from T-cell.

Haemorrhagic myelomalacia associated with extradural T-cell lymphoma should be considered during the differential diagnosis of FeLV positive cats with spinal neurological clinical signs.

\section{Acknowledgements}

The first author's Phd scholarship was cofunded by Conselho Nacional de Desenvolvimento Científico e Tecnológico (CNPq), Brazil and The World Academy of Science (TWAS): CNPq-TWAS Fellowships Programme-2012.

\section{References}

DE LA FUENTE, C.; RÓDENAS, S.; PUMAROLA, M.; AÑOR, S. Dural tear and myelomalacia caused by an airgun pellet in a cat. Canadian Veterinary Journal, Ottawa, v. 54, n. 7, p. 679-682, 2013.
GABOR, L. J.; CANFIELD, P. J.; MALIK, R. Immunophenotypic and histological characterisation of 109 cases of feline lymphosarcoma. Australian Veterinary Journal, Brunswick, v. 77, n. 7, p. 436-441, 1999.

GIANOTTI, G. C.; BEHEREGARAY, W. K.; NÓBREGA, F. S.; LEAL, J. S.; DRIEMEIER, D.; VOLL, R.; CORTESINI, E. A. Mielomalácia hemorrágica progressiva em cão. Acta Scientiae Veterinarie, Porto Alegre, v. 36, n. 1, p. 59-62, 2008.

GÓMEZ, G.; ARANZAZU, D.; ALZATE, A.; CHAPARRO, J. J. Domestic cat paraplegia compatible with Gurltia paralysans nematode. First cases reported in Colombia. Revista Colombiana de Ciencias Pecuarias, Medellin, v. 24, n. 4, p. 663-669, 2011.

HOERLEIN, B. F. Canine neurology: diagnosis and treatment. $3^{\text {th }}$ ed. Philadelphia: W.B. Saunders, 1978. 593 p.

LU, D.; LAMB, C. R.; TARGETT, P. Results of myelography in seven dogs with myelomalacia. Veterinary Radiology \& Ultrasound, Raleigh, v. 43, n. 4, p. 326-330, 2002.

MACEDO, A. S.; SILVA, R. B.; DAL-BÓ, I. S.; GUTIERREZ, L. G.; DRIEMEIER, D.; ALIEVI, M. M. Mielomalácia hemorrágica ascendente secundária à protrusão de disco intervertebral em cão. Acta Scientiae Veterinarie, Porto Alegre, v. 41, n. 1, p. 1-3, 2013.

MARIONI-HENRY, K.; VAN WINKLE, T. J.; SMITH, S. H.; VITE, C. H. Tumors affecting the spinal cord of cats: 85 cases (1980-2005). Journal of the American Veterinary Medical Association, Schaumburg, v. 232, n. 2, p. 237-243, 2008.

MARIONI-HENRY, K.; VITE, C. H.; NEWTON, A. L.; VAN WINKLE, T. J. Prevalence of diseases of the spinal cord of cats. Journal of Veterinary Internal Medicine, Lawrence. v. 18, n. 6, p. 851-858, 2004.

NEGRIN, A.; SCHATZBERG, S.; PLATT, S. R. The paralyzed cat. Neuroanatomic diagnosis and specific spinal cord diseases. Journal of Feline Medicine and Surgery, Vancouver, v. 11, n. 5, p. 361-372, 2009.

NORTHINGTON, J. W.; JULIANA, M. M. Extradural lymphosarcoma in six cats. Journal of Small Animals Practice, Oxford, v. 19, n. 7, p. 409-416, 1978.

PLATT, S. R.; MCCONNELL, J. F.; BESTBIER, M. Magnetic resonance imaging characteristics of ascending hemorrhagic myelomalacia in a dog. Veterinary Radiology \& Ultrasound, Raleigh, v. 47, n. 1, p. 78-82, 2006. 
ROUSSEAUX, C. G.; DOIGE, C. E.; TUDDENHAM, T. J. Epidural lymphosarcoma with myelomalacia in a seven-year-old Arabian gelding. Canadian Veterinary Journal, Ottawa, v. 30, n. 9, p. 751-753, 1989.

TAYLOR, S. M. Disorders of the spinal cord. In: NELSON, R. W.; COUTO, C. G. Small animals internal medicine. $5^{\text {th }}$ ed. St. Louis: Elsevier Mosby, 2014. 1471 p.
VANDEVELDE, M.; HIGGINS, R. J.; OEVERMANN, A. Veterinary neuropathology. Essentials of theory and practice. West Sussex: Wiley-Blackwell, 2012. 200 p.

WEISS, A. T.; KLOPFLEISCH, R.; GRUBER, A. D. Prevalence of feline leukaemia provirus DNA in feline lymphomas. Journal of Feline Medicine and Surgery, Califórnia, v. 12, n. 12, p. 929-935, 2010.

ZILIO, D. M.; BAHR ARIAS, M. V. Mielomalácia hemorrágica progressiva em 14 cães. Pesquisa Veterinária Brasileira, Rio de Janeiro, v. 33, n. 2, p. 219228, 2013. 
